\title{
Grand challenge for low temperature and pressure geochemistry-sparks in the dark, on Earth, Mars, and throughout the Galaxy
}

\author{
Martyn Tranter* \\ Bristol Glaciology Centre, School of Geographical Sciences, University of Bristol, Bristol, UK
}

Keywords: geochemistry of sediments, biogeochemical cycles and processes, glaciology, aqueous geochemistry, chemical weathering

OPEN ACCESS

Edited and reviewed by: Mark Skidmore, Montana State University, USA

*Correspondence: Martyn Tranter m.tranter@bristol.ac.uk

Specialty section:

This article was submitted to Geochemistry,

a section of the journal

Frontiers in Earth Science

Received: 01 October 2015 Accepted: 27 October 2015 Published: 05 November 2015

Citation:

Tranter M (2015) Grand challenge for low temperature and pressure geochemistry-sparks in the dark, on

Earth, Mars, and throughout the Galaxy. Front. Earth Sci. 3:69. doi: 10.3389/feart.2015.00069
The very nature of geochemistry is a grand challenge, since it has the ambition to identify and to gain an in depth understanding of the mechanisms by which the different chemical reservoirs on Earth, the Solar System and beyond, both formed and continue to evolve (Langmuir and Broecker, 2012). Indeed, Earth is unlikely to remain a viable habitat for life as we know it as the Sun declines as an energy source and chemicals continually leak from the atmosphere into space (Kasting, 2010). This may take another 1.5 billion years, so there is time for our descendants to find and colonize another planet, and for we current low temperature and pressure (LTP) geochemists to have a little more fun and find fascination in our attempts to understand how the myriad of interconnected geochemical reservoirs we study evolve over both time and space.

Life is an important geochemical driver in most, if not all, of the environments at or near the Earth's surface. There is an adage that where there is water, there is life (Priscu et al., 1998), and it is a truism that microbes serve to catalyze REDOX reactions, gaining energy for vital processes as a consequence (Madigan et al., 2003). The merry-go-round of geochemical transformations at the Earth's surface is swung in part by life, which is persistent in many forms once it is established (Holland, 1984). We LTP geochemists have the privilege of observing the constitution of the chemical reservoirs we study, from scales that range from sub-nanometers, the spaces between atoms in minerals, to thousands of kilometers, the scale of continents, to light years in the galaxy. Our time scales can equally range from nanoseconds for high energy reactions to the billions of years of chemical differentiation within the Universe. Some would say that an interest in chemicals over these scales and times is the soulless preserve of geeks. We in the thick of it see sparks that trigger our imagination and fill us with awe of the fluxes, transformations, and microbial diversity in the biogeochemical systems that we research. It is another adage that you never stop learning: just when we feel that we have a good understanding of the systems we are studying, some unexpected isotope variation, an anomalous minor element concentration or the mass balance of particular reactions just do not make sense, and we are forced to rethink our biogeochemical view of how our systems stay in balance, or near-steady state.

Low temperature geochemists have a phenomenal legacy of inspirational texts. My 30something years of research are punctuated with reading landmark texts that gave me a sense of just how earth systems self-regulate, and gave me the courage to try to change the view of how my particular subject area was perceived by the wider research community. Here are a few examples. Just how the rock cycle results in chemical differentiation was laid out simply, dramatically, and with such elegance in the Evolution of Sedimentary Rocks (Garrels and Mackenzie, 1971). Bob Garrels also co-wrote a seminal volume on how basic chemical principles could be applied to water-rock interactions (Garrels and Christ, 1965), exemplifying the spectrum of length and time scales that geochemists work with almost simultaneously. Heinrich Holland showed how 
a range of geochemical cycles on Earth have varied over geological timescales (Holland, 1978, 1984). Bob Berner modeled early diagenetic processes (Berner, 1980), and subsequently showed how atmospheric $\mathrm{CO}_{2}$ concentrations were linked to carbonate and silicate weathering cycles over geological timescales (Berner et al., 1983). Wally Broecker showed how the oceans act as one of the most important reservoirs in regulating atmospheric $\mathrm{CO}_{2}$ concentrations over glacialinterglacial timescales (Broecker and Peng, 1982; Broecker, 2002). Tim Drever showed how many different types of fresh and saline waters achieve their composition (Drever, 1997), and the many types of interactions that occur between rocks, waters and gasses have been elegantly summarized by Stumm and Morgan (1996) and Langmuir (1997). These texts could give the impression that everything has been done, and that there are no big challenges left for LTP geochemists. This would be a mistake.

My own field of biogeochemical processes in the cryosphere gives a recent example of how conventional understanding of processes has been turned turtle several times during the last 30 years. The topic is currently an area of great interest for interdisciplinary scientists because these cold environments are now thought of as a biome, rather than as abiotic systems (Priscu and Christner, 2004; Anesio and Laybourn-Parry, 2012). They were once thought to be relatively unimportant in geochemical cycles, but now are seen as potential fertilizers of the polar oceans (Raiswell et al., 2006; Wadham et al., 2013). Glaciers are known to be powerful agents of physical erosion, a combination of abrasion, which produces fine sediment, and fracture/traction, which includes plucking, quarrying, crushing, and joint block removal, producing coarser sediment (Knight, 1999). Much of the finer material produced by subglacial erosion is transported by proglacial meltwater streams for glaciers terminating on land (Hallet et al., 1996). As a consequence, glacial meltwater streams are characteristically turbid, containing high concentrations of predominantly silt-sized sediment. Suspended sediment concentrations typically range from 0.2 to $10 \mathrm{~kg} \mathrm{~m}^{-3}$. Glacier erosion not only produces large quantities of comminuted bedrock, but also liberates the trace reactive components of the bedrock, such as sulfides and carbonates, from the silicate mineral mass (Tranter and Wadham, 2013). Minerals such as apatite are also freely accessible to water, accounting for the high rates of $\mathrm{P}$ weathering in glaciated terrain (Föllmi et al., 2009). Most geochemical reactions, apart from hydrolysis, are microbially mediated (Tranter et al., 2002; Montross et al., 2013). This was a step change for the discipline less than 20 years ago, since glacier beds were formerly thought to be abiotic (Sharp et al., 1999). Key reactions include sulfide oxidation and oxidation of organic matter, both of which drive down the Eh of the waters in regions of the bed distant from inputs of oxygenated surface melt. A limit to the types of reaction that then can occur is imposed by REDOX reactions based around the oxidation of sulfides and the oxidation or disproportionation (methanogenesis) of organic matter, using oxidizing agents such as $\mathrm{NO}_{3}^{-}, \mathrm{Fe}(\mathrm{III}), \mathrm{Mn}(\mathrm{IV})$, and $\mathrm{SO}_{4}^{2-}$. Mass balance constraints are also imposed-reaction extents are ultimately decided by the sulfide and organic matter content of the basal debris and available oxidants.
Another revolution is taking place. The microbial and geochemical reactivity beneath the center of ice sheets overlying crystalline bedrock should be based around sulfides largely (Wadham et al., 2010), and since $\mathrm{O}_{2}$ inputs to the bed would be low, as would the labile organic matter content, geochemical activity would also be low (Skidmore et al., 2000). High geochemical activity beneath thick ice sheets would be largely limited to areas in contact with the legacy organic matter found in overridden soils and sedimentary rocks (Wadham et al., 2012). Clearly, this source of organic matter is limited, and hence microbial ecosystems based around this legacy organic matter are destined to ultimately demise over time, as the sedimentary rock is eroded away. The production of $\mathrm{H}_{2}$ by glacial crushing removes this gloomy fate, and opens up the probability of widespread microbial communities on crystalline bedrocks fuelled by energy generated by physical comminution of bedrock (Telling et al., 2015). Such a scenario increases the probability that subglacial lakes beneath the deep ice of the Antarctic interior hold microbial life (Siegert et al., 2001). Silicate rocks representative of subglacial environments in Greenland, Canada, Norway, and Antarctica were crushed under an inert atmosphere in the lab and wetted. $\mathrm{H}_{2}$ was produced at $0^{\circ} \mathrm{C}$ in all experiments, sufficient to support previously measured rates of methanogenesis under a Greenland glacier (Telling et al., 2015) and in microcosms using subglacial sediments from a Canadian glacier (Boyd et al., 2010).

The physical crushing of silicate minerals causes disruption to the surface bonds of the crystal. A variety of surface radicals can form, including Si॰. This entity produces $\mathrm{H}_{2}$ when wetted with water (Equations 1 and 2).

$$
\begin{aligned}
2 \mathrm{Si} \bullet+2 \mathrm{H}_{2} \mathrm{O} & \rightarrow 2 \mathrm{SiOH}+2 \mathrm{H} \bullet \\
\mathrm{H} \bullet+\mathrm{H} \bullet & \rightarrow \mathrm{H}_{2}
\end{aligned}
$$

This abiotic reaction produces a potent reducing agent from a comminuted silicate rock surface alone, and must occur continually beneath glaciers. $\mathrm{H}_{2}$ is commonly used by certain microbes, for example, to convert organic matter and $\mathrm{CO}_{2}$ to $\mathrm{CH}_{4}$, and to drive other REDOX reactions in place of organic matter. This abiotic $\mathrm{H}_{2}$ may support subsurface ecosystems in higher temperature environments $\left(25-80^{\circ} \mathrm{C}\right)$, such as fault zones (Kita et al., 1982; Sugisaki et al., 1983) and marine hydrothermal zones (Larson et al., 2015). There are no theoretical impediments precluding this at the lower temperatures $\left(-2.5\right.$ to $\left.0^{\circ} \mathrm{C}\right)$ typically found in subglacial aquatic environments. Recent work has demonstrated that this is the case (Telling et al., 2015).

There is another intriguing possibility that potent oxidizing agents can also be formed during crushing, although further experimental work to find these species is necessary. Most silicate minerals in igneous and high-grade metamorphic rocks contain oxygen in the valence state of -1 , rather than -2 , in the vicinity of defect electron holes (positive electron holes or pholes), and in association with peroxyl links (positive hole pairs or PHP) (Freund, 2002; Freund and Sornette, 2007; Balk et al., 2009). These arise when a small amount of $\mathrm{H}_{2} \mathrm{O}$ is incorporated into the silicate mineral crystals during their formation. This causes sites that would normally contain metal ions, such as $\mathrm{Mg}^{2+}, \mathrm{Al}^{3+}$, or $\mathrm{Si}^{4+}$, to be vacant (so-called holes). The charge of the vacancy 
( $\circ$, here assumed to arise from a deficiency of $\mathrm{Ca}^{2+}$ or $\mathrm{Mg}^{2+}$ for simplicity) is partially compensated by the formation of two hydroxyl ions, $\mathrm{OH}^{-}$, formed from the $\mathrm{H}_{2} \mathrm{O}$ and the unsupported $\mathrm{O}^{2-}$ in the crystalline lattice. This arrangement is unstable, and $\mathrm{H}_{2}$ is formed, along with peroxy anion, $\mathrm{O}_{2}{ }^{2-}$ (Equation 3). The latter consists of two tightly bonded $\mathrm{O}^{-}$ions, which form a "selftrapped, localized, electrically inactive point defect" (Freund, 2000) in the silicate crystal.

$$
\mathrm{H}_{2} \mathrm{O}+\mathrm{O}^{2-} \circ \rightarrow \mathrm{OH}^{-}{ }^{-} \mathrm{HO} \rightarrow \mathrm{H}_{2}+\circ^{-}{ }^{2-}
$$

Peroxy anions also form links that bridge between $\mathrm{Al}-\mathrm{O}$ and $\mathrm{Si}-\mathrm{O}$ tetrahedral, as $\mathrm{O}_{3} \mathrm{X} / \mathrm{O}_{2}{ }^{2-} \backslash \mathrm{O}_{3} \mathrm{Y}$ entities, where $\mathrm{X}$ and $\mathrm{Y}$ are $\mathrm{Al}^{3+}$ and $\mathrm{Si}^{4+}$, respectively. These peroxyl links may be exposed at the surface during crushing, and if so, they generate $\bullet \mathrm{OH}$ radicals on wetting. These may in turn generate $\mathrm{H}_{2} \mathrm{O}_{2}$ (Equations 4 and 5).

$$
\begin{gathered}
\circ \mathrm{O}_{2}{ }^{2-}+2 \mathrm{H}_{2} \mathrm{O} \rightarrow \circ 2 \mathrm{OH}+2 \bullet \mathrm{OH} \\
\bullet \mathrm{OH}+\bullet \mathrm{OH} \rightarrow \mathrm{H}_{2} \mathrm{O}_{2}
\end{gathered}
$$

This reaction, and the electron flows that it produces at rock surfaces, is thought to be responsible for the electrical currents that occur in stressed rock, and which could potentially be used to predict earthquakes (Freund, 2000).

Surface radicals on crushed silicate minerals completely change the nature and scope of microbially mediated chemical weathering reactions under ice. The reaction combinations are likely to be complex and dependent on the proximity of the radical production sites to the suite of chemicals in the vicinity, analogous to the chemical reactions occurring in the atmosphere. The concurrence of reactive reducing $\left(\mathrm{H}_{2}\right)$ and oxidizing agents $\left(\mathrm{H}_{2} \mathrm{O}_{2}\right)$ increases the potential of bio-energy being generated

\section{REFERENCES}

Anesio, A. M., and Laybourn-Parry, J. (2012). Glaciers and ice sheets as a biome. Trends Ecol. Evol. 27, 219-225. doi: 10.1016/j.tree.2011. 09.012

Balk, M., Bose, M., Ertem, G., Rogoff, D. A., Rothschild, L. J., and Freund, F. T. (2009). Oxidation of water to hydrogen peroxide at the rock-water interface due to stress-activated electric currents in rocks. Earth Planet. Sci. Lett. 283, 87-92. doi: 10.1016/j.epsl.2009.03.044

Berner, R. A. (1980). Early Diagenesis. A Theoretical Approach. Princeton, NJ: Princeton University Press.

Berner, R. A., Lasaga, A. C., and Garrels, R. M. (1983). The carbonate-silicate geochemical cycle and its effect on atmospheric carbon dioxide over the past 100 million years. Am. J. Sci. 283, 641-683. doi: 10.2475/ajs.283.7.641

Boyd, E. S., Skidmore, M., Mitchell, A. C., Bakermans, C., and Peters, J. W. (2010). Methanogenesis in subglacial sediments. Environ. Microbiol. Rep. 2, 685-692. doi: 10.1111/j.1758-2229.2010.00162.x

Broecker, W. S. (2002). The Glacial World According to Wally. Palisades, NY: Eldigio Press.

Broecker, W. S., and Peng, T.-H. (1982). Tracers in the Sea. New York, NY: Eldigio Press.

Drever, J. I. (1997). The Geochemistry of Natural Waters: Surface and Groundwater Environments, 3rd Edn. Englewood Cliffs, NJ: Prentice Hall.

Föllmi, K. B., Hosein, R., Arn, K., and Steinmann, P. (2009). Weathering and the mobility of phosphorus in the catchments and forefields of the Rhône and Oberaar glaciers, central Switzerland: implications for the global from reactions with the full spectrum of other common REDOXreactive species in silicate rocks, such as $\mathrm{S}$ and $\mathrm{Fe}$. It also presents the possibility of large, relatively refractive organic molecules being partially degraded and activated by oxidation with $\mathrm{H}_{2} \mathrm{O}_{2}$. This combination of factors increases the likelihood that microbial communities can be sustained under glaciers, even on crystalline bedrock. Further, microbial biodiversity is promoted given the spectrum of potential REDOX pairs that could be found in these environments.

This conversion of thermo-mechanical energy, a spark in the dark, into surface free radicals that produce chemical reactions which microbes can utilize is an example of LTP geochemists striving to better understand their geochemical systems using multidisciplinary perspectives. Glacier erosion is pervasive to glaciated terrain, and hence glacier erosion on Mars and other planetary bodies could be providing the vital spark for REDOX processes at least, and possibly extraterrestrial biological processes. There is currently great interest in Mars being a location for persistent microbial life, given evidence of recent seasonal water flow (Ojha et al., 2015). It follows that if life is present on both the Earth and Mars, then life might be considered common to the Solar System as long as water is present, and by the same argument to the Galaxy (https://www.nasa.gov/press-release/nasa-confirmsevidence-that-liquid-water-flows-on-today-s-mars). Here is the Grand Challenge of LTP Geochemistry. Keep challenging current orthodoxy about how your system behaves as a biogeochemical system, and devise new processes, derive new fluxes, and predict the behavior of your system to appropriate perturbations that better fit in with the sound facts at your disposal. The past suggests that there is always room for improvement-go for it.

phosphorus cycle on glacial-interglacial timescales. Geochim. Cosmochim. Acta 73, 2252-2282. doi: 10.1016/j.gca.2009.01.017

Freund, F. (2000). Time-resolved study of charge generation and propagation in igneous rocks. J. Geophys. Res. Solid Earth 105, 11001-11019. doi: 10.1029/1999JB900423

Freund, F. (2002). Charge generation and propagation in igneous rocks. J. Geodyn. 33, 543-570. doi: 10.1016/S0264-3707(02)00015-7

Freund, F., and Sornette, D. (2007). Electro-magnetic earthquake bursts and critical rupture of peroxy bond networks in rocks. Tectonophysics 431, 33-47. doi: $10.1016 /$ j.tecto.2006.05.032

Garrels, R. M., and Christ, C. L. (1965). Solution, Minerals and Equilibria. San Fransisco, CA: Freeman Cooper.

Garrels, R. M., and Mackenzie, F. T. (1971). Evolution of Sedimentary Rocks. New York, NY: Norton.

Hallet, B., Hunter, L., and Bogen, J. (1996). Rates of erosion and sediment evacuation by glaciers: a review of field data and their implications. Glob. Planet. Change 12, 213-235. doi: 10.1016/0921-8181(95)00021-6

Holland, H. D. (1978). The Chemistry of the Atmosphere and Oceans. New York, NY: Wiley

Holland, H. D. (1984). The Chemical Evolution of the Atmosphere and Oceans. Princeton, NJ: Princeton University Press.

Kasting, J. (2010). How to Find a Habitable Planet. Princeton, NJ: Princeton University Press.

Kita, I., Matsuo, S., and Wakita, H. (1982). H2 generation by reaction between $\mathrm{H} 2 \mathrm{O}$ and crushed rock - an experimental study on $\mathrm{H} 2$ degassing from the active fault zone. J. Geophys. Res. 87, 789-795. doi: 10.1029/JB087iB13p10789 
Knight, P. G. (1999). Glaciers. Cheltenham: Stanley Thornes (Publishers) Ltd.

Langmuir, C. H., and Broecker, W. S. (2012). How to Build a Habitable Planet. The Story of Earth from the Big Bang to Humankind. Princeton, NJ: Princeton University Press.

Langmuir, D. (1997). Aqueous Environmental Geochemistry. New Jersey, NJ: Prentice-Hall.

Larson, B. I., Lang, S. Q., Lilley, M. D., Olson, E. J., Lutpon, J. E., Nakamura, K., et al. (2015). Stealth export of hydrogen and methane from a low temperature serpentinization system. Deep Sea Res. II. doi: 10.1016/j.dsr2.2015.05.007. [Epub ahead of print].

Madigan, M. T., Martinko, J. M., and Parker, J. (2003). Biology of Microorganisms. Upper Saddle River, NJ: Prentice Hall.

Montross, S. N., Skidmore, M., Tranter, M., Kivimäki, A.-L., and Parkes, R. J. (2013). A microbial driver of chemical weathering in glaciated systems. Geology 41, 215-218. doi: 10.1130/G33572.1

Ojha, L., Wilhelm, M. B., Murchie, S. L., McEwen, A. S., Wray, J. J., Hanley, J., et al. (2015). Spectral evidence for hydrated salts in recurring slope lineae on Mars. Nat. Geosci. 8, 829-832. doi: 10.1038/ngeo2546

Priscu, J. C., and Christner, B. C. (2004). "Earth's icy biosphere," in Microbial Diversity and Prospecting, ed A. T. Bull (Washington, DC: ASM Press), $130-145$.

Priscu, J. C., Fritsen, C. H., Adams, E. E., Giovannoni, S. J., Paerl, H. W., McKay, C. P., et al. (1998). Perennial Antarctic lake ice: an oasis for life in a polar desert. Science 280, 2095-2098. doi: 10.1126/science.280.5372.2095

Raiswell, R., Tranter, M., Benning, L. G., Siegert, M., De’Ath, R., Huybrechts, P., et al. (2006). Contributions from glacially derived sediment to the global iron (oxyhydr)oxide cycle: implications for iron delivery to the oceans. Geochim. Cosmochim. Acta 70, 2765-2780. doi: 10.1016/j.gca.2005.12.027

Sharp, M., Parkes, J., Cragg, B., Fairchild, I. J., Lamb, H., and Tranter, M. (1999). Widespread bacterial populations at glacier beds and their relationship to rock weathering and carbon cycling. Geology 27, 107-110.

Siegert, M. J., Ellis-Evans, J. C., Tranter, M., Mayer, C., Petit, J.-R., Salamatin, A., et al. (2001). Physical, chemical and biological processes in Lake Vostok and other Antarctic subglacial lakes. Nature 414, 603-609. doi: 10.1038/414603a

Skidmore, M. L., Foght, J. M., and Sharp, M. J. (2000). Microbial Life beneath a High Arctic Glacier. Appl. Environ. Microbiol. 66, 3214-3220. doi: 10.1128/AEM.66.8.3214-3220.2000
Stumm, W., and Morgan, J. J. (1996). Aquatic Chemistry. Chemical Equilibria and Rates in Natural Waters. New York, NY: Wiley Interscience.

Sugisaki, R., Ido, M., Takeda, H., Isobe, Y., Hayashi, Y., Nakamura, N., et al. (1983). Origin of hydrogen and carbon dioxide in fault gases and Its relation to fault activity. J. Geol. 91, 239-258. doi: 10.1086/628769

Telling, J., Boyd, E. S., Bone, N., Jones, E. L., Tranter, M., Macfarlane, J. W., et al. (2015). Rock comminution as a source of hydrogen for subglacial ecosystems. Nat. Geosci. 8, 851-855. doi: 10.1038/ngeo2533

Tranter, M., Sharp, M. J., Lamb, H. R., Brown, G. H., Hubbard, B. P., and Willis, I. C. (2002). Geochemical weathering at the bed of Haut Glacier d'Arolla, Switzerland - a new model. Hydrol. Process. 16, 959-993. doi: 10.1002/hyp.309

Tranter, M., and Wadham, J. L. (2013). "Geochemical weathering in glacial and proglacial environments," in Treatise on Geochemistry, Vol. 5, Surface and Ground Water, Weathering, and Soils, 2nd Edn., ed J. I. Drever (Oxford; San Diego, CA: Elsevier), 153-174.

Wadham, J. L., Arndt, S., Tulaczyk, S., Stibal, M., Tranter, M., Telling, J., et al. (2012). Potential methane reservoirs beneath Antarctica. Nature 488, 633-637. doi: $10.1038 /$ nature 11374

Wadham, J. L., De'Ath, R., Monteiro, F. M., Tranter, M., Ridgwell, A., Raiswell, R., et al. (2013). The potential role of the Antarctic Ice Sheet in global biogeochemical cycles. Earth Environ. Sci. Trans. R. Soc. Edinb. 104, 55-67. doi: $10.1017 /$ S1755691013000108

Wadham, J. L., Tranter, M., Skidmore, M., Hodson, A. J., Priscu, J., Lyons, W. B., et al. (2010). Biogeochemical weathering under ice: Size matters. Glob. Biogeochem. Cycles 24, GB3025. doi: 10.1029/2009GB 003688

Conflict of Interest Statement: The author declares that the research was conducted in the absence of any commercial or financial relationships that could be construed as a potential conflict of interest.

Copyright (c) 2015 Tranter. This is an open-access article distributed under the terms of the Creative Commons Attribution License (CC BY). The use, distribution or reproduction in other forums is permitted, provided the original author (s) or licensor are credited and that the original publication in this journal is cited, in accordance with accepted academic practice. No use, distribution or reproduction is permitted which does not comply with these terms. 